\title{
エンジン制御コントローラの現状と今後の動向
}

\section{Present Status and Future of Equipment for Engine Control}

中本 勝也 （三菱電機株式会社）

Katsuya Nakamoto, Mitsubishi Electric Corporation

Key Words: <Key Words>

自動車用エンジン制御 運転性能向上 排気ガス低減 低燃費化 メモリ容量 CPU ROM RAM 高密度䒠装 $E C U$ 小型化 電子部品 システムLSI プリント基板 コネクタ 耐環境性能 耐熱性 防水ECU EMI性能

1. まえがき

現在の自動車には多数の電子制御装置力搭載されており、運車云性向上、

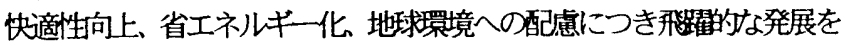
遂けてているそのため電子制御装置い内蔵されているエレクトロニクス 関連部品に求められる機能、性能は高度化の一途をたどっている。 本稿で、その中心的な役割を担っているエンジン制許ユニットについ ての処理能力強化、小型化、信頼牲向上の技術動向と最近の実装技術の 適用事例を紹介する。

2.エンジン制御ユニット概要(Engine Control Unit : ECU)

自動車用エンジン制御に要求される主な項目は、高出力化，低㜣費化 排汮ガス低减、運転性能向上である。これらの項目に対応して、精密空 燃比制御，電子スロットル制御，吸気\&排気バルブの可変夕イミンク制 御、各気筒独立制御の増加、等、制御要素の増加之制御の精密化力淮九 でいる。同時に安全性強化之整備性向上の目的からオンボード自己診断 規制対応制御も年々高度化している。更にはオートマチックトランスミ ッション・電子スロットル制御・シャーシ系制御・などとの協調制御の 増加により、ECUに要求される処理能力は年々增大している。

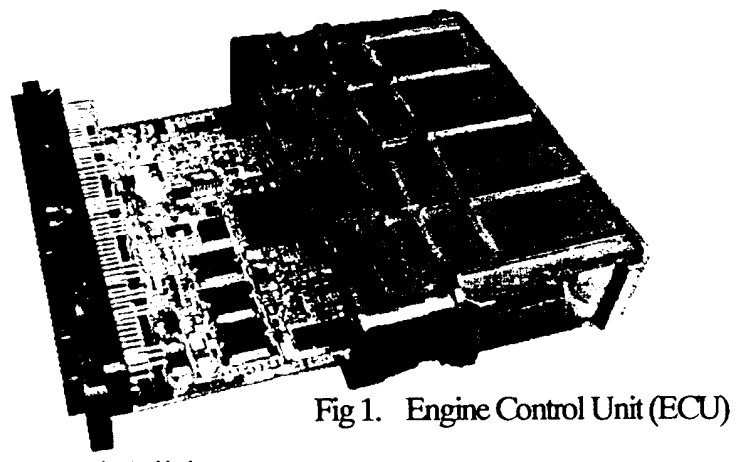

3. ECUの処理能力

3-1. ECU機能向搪大

制御項目の堌加之制御内容の高度化に伴い、セン等の入力信号とア クチュエ一夕などへの出力信号の数力哖々増加している。この機能拡大 はECUのコネク夕端子数より推移を見ることができるが、“80年に は32極であったものが、, 85 年には 52 極，90年 76 極，95年 93 極、, 00 年 119 極，03年 140 極と增大傾向にある。但し、 今後は車内LAN採用による分散処理化が進さため、140極〜 160 極程度でコネク夕端子数の拡大は止まると予想される。

図2に・90年以降の主要制卸機能の推移を示す。

3-2.メモリ容量

増加する制御機能を実現するためにはマイコンのROMやRAMな どのメモリ容量を増やす必要があり、加えてソフトウエア作成の効率化 と信頼性を確保するための上位語、ブロック線図からのプログラム自 動生成、浮動小数点演算対応、リアルタイムOS採用などの理由で、今 後もメモリ容量は増加を続けると考える。

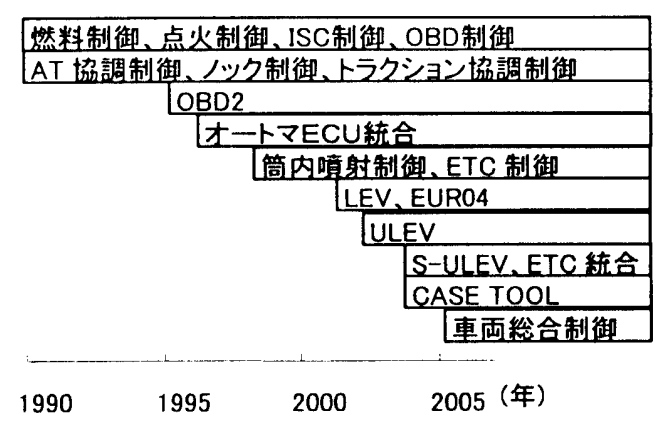

Fig 2. Changes of the ECU main functions

3-3. マイコン処理速度

制御機能の増加之高度化に対态するためにメモり容量を増加させる 之同時にマイコン内CPU (中央演算装置) 処理速度の高速化をしなけ ればならない。また、アナログ信号のデジタル処理化などの高速演算機 能も抗大傾向にあり、C PU高速化の必要性力哖々増している。 これには動作周波数高速化やキャッシュメモリ搭載ＣPUの機能を補 完する浮動小数点演算ユニットやデジタル信号プロセッサの搭載が倠 むと考える。図3にマイコンの主要性能の変選を示す。

34. メモリの多様化

従来、マイコンのROMにはマスクROMやワンタイ れていたが、近年ではECU組立完了後にコネク夕端子よりプログラム を書入み可能なF L A SHメモリを使うことが主流となってきており、 これによって、プログラム固定からECU完成までの期間知縮、および 八一ドウェアの標隼化、生産性向上を図っている。又、故障診断結果記 憶、センサやアクチュエータの個々の特性值記憶、イモビライザ 盜難 防止装置) のI Dコード記意、エンジン制御システムのばらつき記湆な ど、バッテリを外しても消えないメモリ搭載の要求が増えてきており、 EE P R OM(Electric Erasable PROM)搭載がー般化している。

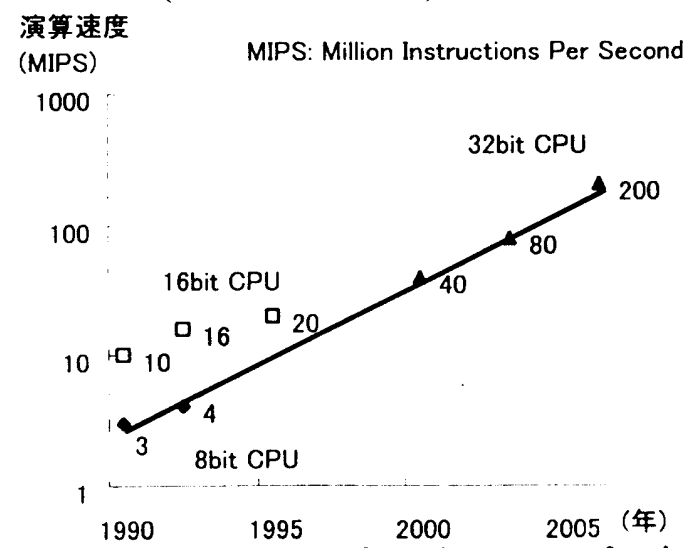

ROM容量 (Kbyte)

1000

100

Fig 3. Changes of the microprocessor functions

日本機械学会東海支部第52期総会講演会講演論文集（'03. 3. 14-15）No.033-1 
ECUの機能力増力吗る一方で、車両における電子制御機器の増大、 車室内スペースの居住性への優先的利用や、ECU取付け場所の多様化 により、ECUに対する小型化の要求は高い。

次に小型化の要素技術について紹介する。

\section{1. 電子部品の小型化}

現在、ECUの電子部品はガラスエポキシ基板に表面夷装するのが主 流であるが、電子部品の奏装密度を上げる方法のひとつは電子部品の小 型化である。図4にディスクリート部品およびI Cパッケージの小型化 の変選を示すが、チップ抵抗では1.0mm×0. $5 \mathrm{~mm}$ サイズ、I C ではピン間0. $5 \mathrm{~mm}$ ピッチが採用されている。今後のさらなる I Cピ ン数の増加に対しては、F B GAやC S P(Chip Size Package) 几移行する 方向にあり、既に量産化を開始している製品もある。

尚、エンジン制御ECUは、信頼性確保之低コスト化を両立させるため に、部品の小型化は携带機器と比較して数年遅れる傾向にあるが、無修 正で $100 \%$ 良品を製造することでECUの高品質化を追求するのが 特徴である。

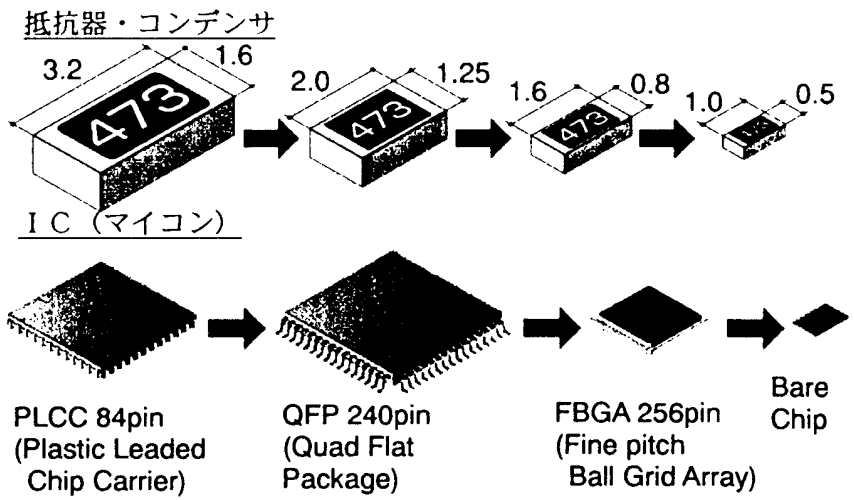

Fig 4. Downsizing of the electronic components

42. 回路の高集積化

ECUの回路は主にセンサやアクチュエータなどの制御関俥部品との インターフェイス回路と電源回路、マイコン周加回路から成り立ってい る。これらのマイコン周边回路を集約化することによりECUの小型化が 可能になるとともに、集約化はコスト低减 部品点数低减による品質向 上にも頁献する。従来から集約化の方法として、HICHybrid ICY化、デ ジタルカタタ I C化、アナログカスタムI C化、アナログデジ夕ル混 在力ス夕ムUC化などの手法力゙用いられ、機能每に力ス夕ムI C化を行っ ていたが、最近の事例ては、システムLS I 技術を活用して複数機能の カスタム I Cを統合化して行く傾向にある。

それに伴い I C開発工数が大きくなるため、図5に示すように、アナロ グデジタ混在力スタムICのデジル部を、シテムL S I の設計手法で あるHDL(Hardware Description Language)を用いてECU設計者が淔接 話述することにより、IC開発の設計期間を縮小するとともに、リソース の再活用を可能にする開発方式力彩用されている。

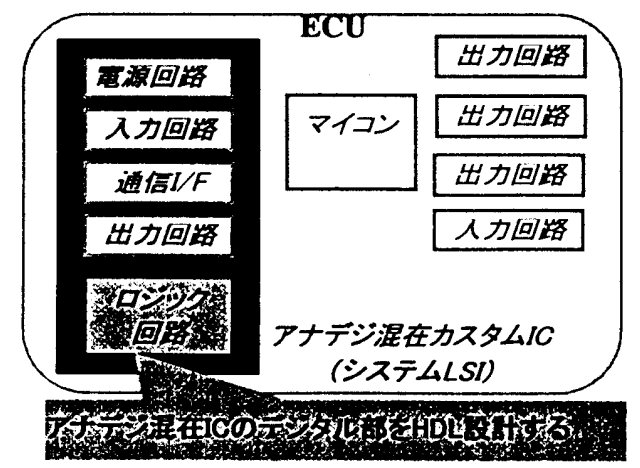

Fig 5. Integrated circuit (System LSI)
43. プリント基板の高密度化

電子部品を高密度に実装するためには配線の高密度化も必要である。 基板の材料としては、ベアチップなどを用いた高密度化には多層セラミ ック基板か適しているが、コスト高となるため、現在もガラスエポキシ 基板力注流となっている。配楾の高密度化の方法としては（1)配線ピッ チの微細化 (2)基板の多層化 (3)ブラインドバイヤの採用 があげら れる。一方、エンジン制御E CUの特徽として、マイコン周辺部は I C 小型化とパター集中により超高密度配線が必要であるが、逆に点火系 やアクチュエータのノイズクロストーク抑制のために治面距離力必要 な部分もあり、高密度と電力パターンを 1 枚の基板上に混在設計する技 術が必要である。現在、配線幅亡間腙は各々 $0.15 \mathrm{~mm}$ 、基板層数は 2層から6層がエンジン制御ECUでは一般的である。

4-4. コネク夕高密度化

ECUのサイズはコネクタによって制約されると言っても過言では ない。入出力信号数の増加に伴いコネクタのピン数も増吅するため、 $\mathrm{E}$ CUの小型化のためには、コネクタの高密度化が重要なファクターであ る。高密度化手法としては、ピンの小型化と多段化，小径ワイヤー八ネス採用が上げられ、3．1項のコネク夕極数增加に対してECUサイ ズを大型化することなく実現している。

5. 而攐境性

5-1. ECU搭載場所

従来ECUは車室内に搭載されていたが、近年では剧住スペース確保 の目的でエンジンルーム搭載か推進されている。ECUをエンジンルー ムに搭載するための主要技術である防水性と而熱性につき紹介する。 5-2. 防水 $\mathrm{ECU}$

エンジンルームはオープンスペースであるため、雨天走行時の被水、 車两整满時の高压水で洗浄時の被水に而元，電子回路力゙被水しない样に 保護しなければならないここために防水コネクタと密閒ケ一ス構造を 取り、運転状態で変化するE CU温度による内部王力変動（呼吸作用） 低減の撥水フィルターを設けている。図6に防水ECUの構造例を示す。

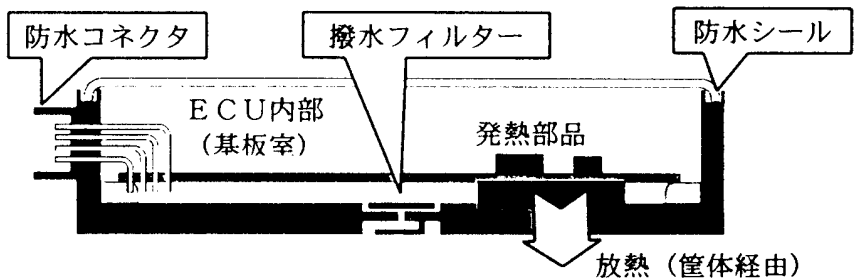

Fig 6. Structure of the waterproof ECU

5-3. 而爇性

エンジンルーム搭載の場合、搭載場所によって最高温度は異なるが、 ECU周册温度が $100^{\circ} \mathrm{C}$ 前後まで上昇するため、マイコンに代表され る電子部品も $105^{\circ} \mathrm{C} 、 125^{\circ} \mathrm{C}$ 高温度仕様品を用途に合せて採用し ている。また、モ一夕用など大電流の駆動回路内藏によるECU内部発 熱も課題となっており、低発熱可路の工夫と低発熱素子の採用、並ひに 放熱構造の工夫を行っている。

54. EM I 性能（不要電磁被放射）

ECUの高機能高性能化に伴うマイコンの動作周波数增加やスイッ チング制御化、大電流駆動回路内蔵の增加により、ノイズの発生要因が 増えている。また一方ではオ一ディオの高機能化やモジュール化による パワー系ハーネスとオーディオ系八ーネスの近接など、ノイスに対する 感度も高くなっている。反面、ノイズ低减に対する要求は年々谖しくな つており、ECU本体加の放射のみでなく、車両のワイヤーハーネス に誘起して放射されるEM I も考虑し、発生ノイズを如何に抑えるかが 課題となる。民生機器ではシールドによる遮敬がー般的に用いられるが 図 1 に示すECUでは金属による遮枚を行わず以下の工夫により樹脂 ケースで対処している。(1)マイコン自身のノイズレベル低减 (2)゚ター ン設計の最商化、(3)ノイス吸收部品の最適化、(4)電子部品の高集積化 以上 